\title{
MUHAMMADIYAH: CONTESTING IDEOLOGIES BETWEEN PROGRESSIVE ISLAM AND TRADITIONAL
}

\author{
Mursalim, Usman Jafar, Barsihannor \\ The Youth of Muhammadiyah Organization \\ Jl. Gn. Lompobattang No.201, 90141, Pisang Sel., Kec. \\ Ujung Pandang, Kota Makassar, Sulawesi Selatan 90141 \\ Email: mursalimmunir63@gmail.com
}

\begin{abstract}
The research focuses on examining the dynamics of variants of Islamic thought in Muhammadiyah, especially progressive Islamic thought and conservative Islam. The main objective of this research is to identify how the contestation model of the two variants strengthens its hegemony. To achieve this goal, library research was carried out using qualitative-descriptive-analytical methods and utilizing two approaches, namely historical perspectives and sociological knowledge. Based on the available literature, it is found that two tendencies of thought in Muhammadiyah, namely Progressive Islamic thought and Conservative Islam, contradict each other in areas which in the context of Muhammadiyah are closely related to the ideological dimension, namely the methodology of thought and thought construction. Contestation in this aspect has implications for the emergence of a more practical contestation, namely the efforts to market their ideas and beliefs through organizational structural and cultural channels outside the organizational authority.
\end{abstract}

Keywords: Muhammadiyah, Islamic Thought, Contestation, Progressive, Conservative. 


\section{Introduction}

The early 20th century AD was the starting point for the rise of the Dutch East Indies (hereinafter Indonesia). This revival was marked by the mushrooming of various movement organizations with a reformist-modernist and nationalist character. This was a response to the situation in Indonesia which in various aspects was very backward due to the Dutch colonial rule. The tendencies of the movements of these organizations are religious, educational, social, cultural, and political movements. For example, Syarikat Dagang Islam, Syarikat Islam, Jami'at Khair, Budi Utomo, and Muhammadiyah.

Muhammadiyah is one of them who is very prominent. This organization is thick with socio-religious and educational movements. Various achievements and achievements have been realized, but behind its greatness and activities, it turns out that this organization that established itself as modern cannot be separated from criticism, both internal and external. Amin Abdullah said that Muhammadiyah seemed to be modern only in organizational management, bureaucracy, institutions, and charities, but not modern in the area of thought. Similarly, criticism was also made by Haedar Nashir that Muhammadiyah seemed to have lost the spirit of enlightenment from KH Ahmad Dahlan, who had a rainbow army in the education movement, and his

${ }^{1}$ Deliar Noer, Modern Islamic Movement in Indonesia 1900-1942 (Jakarta: LP3ES, 1980), p. v. 
business charities who dared to make breakthroughs. Muhammadiyah appears to be powerful in its distribution and physical progress but seems to have lost its oasis of thought and spirituality. ${ }^{2}$

Some people consider the stagnation of thought within Muhammadiyah as a result of the proliferation of conservative religious movements when the reformation took place with the restoration of democracy. The era of openness and freedom in democracy was put to good use by conservative groups, they multiplied and then filtered into various established religious organizations including Muhammadiyah. This phenomenon has received a critical response from the progressive-liberal Muhammadiyah figure who has become a new variant at the other end. In the contemporary Muhammadiyah context, the influence of the two characteristics of thought develops significantly among the citizens, elites, and leaders of Muhammadiyah. Both have been transformed into new variants that carry an ideology that is somewhat different from the mainstream adopted by Muhammadiyah citizens. In this study, the researcher categorizes the two variants of thought as Conservative Islamic thought and Progressive Islamic thought, both claiming to fight for Muhammadiyah's agenda and feel the most Muhammadiyah. It is at this point that conflicts of

${ }^{2}$ Haedar Nashir, Muhammadiyah Ideology in the Middle of Contemporary Movements, in Reactualization and Contextualization of Advancing Islam in the Middle of Global Civilization (South Jakarta: Al-Wasat Publishing House, 2012), p. 74. 
thought or what researchers call ideological contestation are no longer inevitable.

\section{Literature Review}

Studies on Muhammadiyah, especially aspects of religious thought, have been carried out by various academics, both Muhammadiyah insiders and outsiders. Several research results are related to the theme of this study, such as: First, the book by Pradana Boy, Defending Pure Islam, this book is the result of a thesis research that examines the socio-religious dynamics of Muhammadiyah in the period 2006-2007 which indicates the phenomenon of conservatism within Muhammadiyah stronger. Second, Ahmad Nur Fuad's work, From Reformers to Transformatidf: Muhammadiyah's Religious Intellectual Dialectics. This book is a description that describes the continuity and discontinuity of Muhammadiyah's religious thought. Ahmad Nur Fuad concluded that the construction of Muhammadiyah religious thought was more or less influenced by the ulama who became the elite. Third, the results of Carool Kersten's research which was recorded under the title Fighting Wacana: The Struggle for Discourse of Indonesian Muslims in the Reform Era. Carool Kersten mapped Islamic thought in Indonesia, especially at the end of the New Order era until the Reformation. Kersten analyzed the ideas and development of Indonesian Islamic intellectualism, especially among young thinkers who are struggling over discourse, between conservatives, moderates, liberals, post-traditionalists, post- 
modernists, and progressives. Some of these young thinkers were affiliated with Nahdlatul Ulama and Muhammadiyah.

Third, a book entitled Illusion of an Islamic State: Expansion of Transnational Movements in Indonesia. This book is the result of research carried out collectively for two years under the auspices of the Lib For All Foundation. ${ }^{3}$ This book reveals the origin, ideology, agents, agenda, of Islamic movements in Indonesia which are identified as transnational Islam; their strategy in fighting for their beliefs and infiltration towards society and religious groups that are considered moderate, such as NU and Muhammadiyah. Fourth, the thesis of Hamzah F's research results at the Postgraduate Program at Alauddin State Islamic University in Makassar in 2016 entitled The Thesis of Advancing Islamic Thought 19121923. This thesis is an attempt to trace the foundation or basis of Islamic thought that progressed by Muhammadiyah in the formative period or the period of its founding which was documented in various documents.

${ }^{3}$ This research involved two teams consisting of several intellectuals who have different backgrounds, including religious organizations. The Jakarta team consisted of C. Holland Taylor, Hodri Ariev, Dr. Ratno Lukito (research advisor), Ahmad Gaus AF, who was responsible for KH. Abdurrahman Wahid. The Yogya team consists of Dr. Zuly Qodir, Dr. Ratno Lukito, Dr. Agus Nuryatma, and Dr. Rizal Panggabean and is assisted by 27 researchers. The Yogya team is under the coordination of Prof. Munir Mulkan as chairman. Abdurrahman Wahid, et al, Illusion of an Islamic State (Jakarta: The Wahid Institute, 2009), p. 48-49. 
Some of the research results mentioned above elaborate more or less on Muhammadiyah, but no one has specifically studied contestation, especially in the ideological dimension, especially the progressive and conservative variants of Islam within Muhammadiyah. This is an important blank space to fill so that this research becomes relevant.

To properly understand the roots of the differences between the two variants of progressive and conservative Islamic thought in the context of this research, several scientific approaches are used. First, the social sciences in this case the sociology of knowledge which was initiated by Karl Mannheim. The basic principle of Karl Mannheim's sociology of knowledge is that no way of thinking or knowledge can be understood if its social origins are not classified. For Karl Mannheim, human knowledge cannot be separated from individual subjectivity, social and psychological backgrounds in the process of knowledge construction. ${ }^{4}$

Second, the historical theoretical framework. This research is based on a historical theoretical framework that refers to the dialectic of diachronic and synchronic moments, ${ }^{5}$ this framework is used to see Muhammadiyah as a whole in

${ }^{4}$ Karl Mannheim, Ideology and Utopia: Uncovering the Connection of Thought and Politics, trans. F Budi Hardiman, (Yogyakarta: Kanisius, 1991), p. 291.

${ }^{5}$ The study of synchronic moments makes it possible to show the historical conditions of a social structure, the study of diachronic time can reveal a network of traces and memories of a long history. Yudi Latif, Muslim Intelligence and Power: The Genealogy of 20th Century Muslim Intelligence (Bandung: Mizan, 2005), p. 8-10. 
its historical span. One of the important aspects to highlight by utilizing the historical framework is the dynamics of Muhammadiyah thought, both institutionally and sparked by its figures.

In addition to the two theoretical frameworks above, the researcher also uses discourse analysis, but it is not as specific as using the analysis model proposed by the experts. Ideology is one of the central aspects of discourse analysis. This is indeed quite reasonable because texts, conversations, and so on are derivatives or practices of ideology. ${ }^{6}$

\section{Research Methods}

This research is library research using the descriptive qualitative method. Research data is obtained from documented libraries, such as books, archives, journals, papers, etc. which are related to the study theme. In the context of Muhammadiyah, the dynamics of Islamic thought discourse involves two variants, namely Progressive Islam and Conservative Islam, which can be traced to a social science approach in this case the sociology of knowledge, history, and discourse analysis.

Researchers mapped two kinds of data sources, namely primary data sources and secondary data sources. The

${ }^{6}$ Eriyanto, Discourse Analysis: Introduction to Media Text Analysis. Cet. V; Yogyakarta: LKIS, 2006), p. 13. 
primary data referred to are books by several intellectuals in Muhammadiyah circles. Meanwhile, secondary sources are books or other sources relevant to this study. The collected data is then classified, verified, analyzed and finally carried out an abstraction to conclude.

\section{Progressive Islam and Conservative Islam: A Definition}

Progressive Islam in Omid Safi's definition is Islam that carries a contextualization of a fresh, open, friendly, and responsive interpretation of humanitarian issues. Progressive Islam promotes and offers an Islamic method that emphasizes the creation of social justice, gender equality, and pluralism. A progressive Muslim must be willing to take part in the struggle for social justice. From the above definition, it is clear that the progressive Islam proclaimed by Omid Safi pays full attention to issues up to the enforcement of social justice, not only dwelling on the theoretical debate, but more than that Islam must be grounded with values upholding human values, pluralism, and always forward-oriented. This can be seen in issues that are the domain of progressive Islam as mentioned by Omid Safi, namely: discrimination against religious or ethnic minorities, gender injustice, violations of human rights (HAM), freedom of speech, practicing one's religion, unfair distribution of wealth. balanced, and until the exercise of authoritarian power. ${ }^{7}$

${ }^{7}$ Aminudin, "Progressive Islam: An Analysis of Omid Safi's Thought", Farabi Journal of Constructive Thought in the Field of Philosophy and Da'wah 16, no. 2 (2019): h. 153. 
The term conservative is often confronted with progressive which means forward and always forwardoriented. Conservative concerning religion is called religious conservatism and in academic discourse, it is called religious conservatism or religious conservativism, which is defined as the understanding and practice or behavior of conservative religion, namely strictly adhering to the holy book or teachings, orthodoxy, and traditions that are considered the most correct. ${ }^{8}$

Azyumardi Azra in his resonance, Religious Conservatism (2), argues that religious conservatism firmly rejects the interpretation, understanding, and renewal of religious thought and practice that follows modern developments. ${ }^{9}$ According to him, the phenomenon of religious conservatism occurs in almost all religions, but in Indonesia, this phenomenon is most visible among Muslims due to demographic realities; the majority of Indonesia's population is Muslim. ${ }^{10}$

${ }^{8}$ Azyumardi Azra, "Religious Conservatism 2", Republika.Co.Id. https://republika.co.id/berita/pwam8a282/konservatisme-agama-2 (24 September 2020).

${ }^{9}$ Azyumardi Azra, "Religious Conservatism 2", Republika.Co.Id. 16 August,

https://republika.co.id/berita/pwam8a282/konservatisme-agama-2 (24 September 2020).

${ }^{10}$ Azyumardi Azra, "Religious Conservatism 2", Republika.Co.Id. 16 August, 2019. https://republika.co.id/berita/pwam8a282/konservatisme-agama-2 (24 September 2020). 
Martin van Bruinessen, as quoted by Din Wahid, defines conservative Islam as a thought that rejects attempts to interpret Islamic teachings liberally and progressively, besides that it also tends to maintain a standardized social system and interpretation. Efforts to understand conservative Islamic thought as the opposite of progressive Islam can be seen from the grouping of six trends in contemporary Islamic thought initiated by Abdullah Saeed as previously mentioned. If you follow Van Bruinessen's definition, what can be classified into conservative Islam from this trend of thought is that of a legalist-traditionalist style that has the aim of finding authentic Islam as early Islam and puritan theological yearning for inner fulfillment, ${ }^{11}$ both tend to textually understand religious teachings and reject the use of scientific methodologies that are thought to come from the West in understanding sacred texts.

The conservative Islamic thought referred to in this study cannot be separated from the aforementioned descriptions, namely, those which strictly, orthodox, and textually understand Islamic teachings; rejects methodological tools that he considers to come from outside the Islamic tradition such as hermeneutics; reject the ideas of pluralism and religious liberalism.

\section{Genealogy of Progressive Islam and Conservative Islam}

${ }^{11}$ Fathurrosyid, "Abdullah Saeed's Version of Progressive Islam (Efforts to Face Contemporary Religious Problems)", Al-Ahkam 10, no. 2 (2015): h. 296. 
Chronologically, Munir Mulkhan mapped the movement of Muhammadiyah religious thought into four phases, namely: creative and inclusive, ideological, sharia spiritualization or sensitization, and ideological romanticism. The religious pattern of the early Muhammadiyah or the first phase is closely related to the central figure of $\mathrm{KH}$ Ahmad Dahlan, which is more interpreted as an effort to spiritualize, rationalize, and functionalize or pragmatize teachings in the joints of community life. ${ }^{12}$ The ideological phase, namely after $\mathrm{KH}$ Dahlan, saw many changes in Muhammadiyah's style. This phase is marked by efforts to systematize, interpret, and reinterpret the successor generations who are more purifications in character. ${ }^{13}$ Figur yang paling berpengaruh pada fase perubahan ini menurut Munir Mulkhan adalah Mas Mansur. ${ }^{14}$ After Mas Mansyur, there were scholars such as Ki Bagus Hadikusuma, A.R. Sutan Masyur, Ahmad Badawi, Faqih Usman, A.R. Fakhruddin, and Djarnawi Hadikusuma. The elite Muhammadiyah ulama mentioned above have religious-intellectuals that are more or less the same as Mas

${ }^{12}$ Azaki Khoirudin and Mu'arif, "Editor's Introduction" in Amin Abdullah, Fresh Ijtihad: Manhaj of Islamic Thought of Muhammadiyah in the Era of Disruption (Yogyakarta: Suara Muhammadiyah, 2019), p. xii-xiii. Hamzah F, Muhammadiyah's Progressing Islamic Thought Base 1912-1923, p. 72 82.

${ }^{13}$ Azaki Khoirudin and Mu'arif, "Editor's Introduction" in Amin Abdullah, Fresh Ijtihad: Islamic Thought Manhaj Muhammadiyah in the Era of Disruption, p. xii-xiii.

${ }^{14}$ Nurhayati, et al, Mubammadiyah: In the Perspective of History, Organization and V alue Systems (Yogyakarta: Trust Media Publishing, 2018), p. 84-97. 
Mansyur, their religious views have an important influence on Muhammadiyah religious discourses, both on the theological aspects, as well as law and politics. This period lasted mainly from 1942 to the end of $1980 .{ }^{15}$ The third phase or the spiritualization of sharia, in this phase the understanding of shari'ah has a more spiritual or Sufistic tendency, besides that there is also a more open reformulation of the ijtihad methodology which is marked by the affirmation of the burhani approach and the inclusion of the irfani approach in Muhammadiyah manhaj. This era began with the emergence of a modern Western highly educated generation who later became Muhammadiyah elites, including M. Amin Rais, Ahmad Syafii Maarif, Munir Mulkhan, Moeslim Abdurrahman, Dawam Raharjo, and Amin Abdullah. All of them have Western education, but in religious knowledge it is sufficient. ${ }^{16}$

The stretch and style of religious thought that were encouraged by the intellectuals above received two different responses, first resistance, and second appreciation. Those who oppose it consider that the actions and ideas carried out by the intellectual elite who graduated from modern Western education are dangerous and inconsistent with Muhammadiyah's ideals. The resistance of conservative

${ }^{15}$ Ahmad Nur Fuad, From Reformism to Transformative (Malang: Intrans Publishing, 2015), p. 7-8.

${ }^{16}$ Azaki Khoirudin and Mu'arif, "Editor's Introduction" in Amin Abdullah, Fresh Ijtihad: Islamic Thought Manhaj Muhammadiyah in the Era of Disruption, p. xv. 
groups was very evident in the arena of the 45th Muhammadiyah Congress in Malang with the election of Dien Syamsuddin and the throwing of Muhammadiyah's progressive elites from the 13th formation.

\section{Ideological Contestation of Progressive Islamic Thought and Conservative Islam}

In discourse analysis, ideology is a central concept, this is because conversations, texts, and others are practical forms of ideology. Therefore, the ideology for the contesting group was built to reproduce and legitimize its dominance. ${ }^{17}$ Then in the Mannheim sociology of knowledge, ideology is understood as an attempt to hegemony the way of life of certain people and groups. As quoted by Siti Ruhaini, Fineman uses the concept of ideology as a discursive transmission system that encompasses a set of principles and concepts that link discusses with power. Operationally the discursive dimension can be interpreted as a strategic guide to internalizing a view of life that contains ways of thinking, beliefs, and ideals. ${ }^{18}$ Haedar Nashir interprets ideology as a system of understanding a person or a group that contains

13.

${ }^{17}$ Eriyanto, Discourse Analysis: Introduction to Media Text Analysis, p.

${ }^{18}$ Siti Ruhaini Dzuhayatin, Mubammadiyah Gender Regime: Contestation of Gender, Identity and Existence (Yogyakarta: Suka Press UIN Sunan Kalijaga Yogyakarta \& Student Library, 2015), p. 163-164. 
ways of thinking, knowledge, and ideals of struggle regarding life. $^{19}$

In the context of Muhammadiyah, by using the framework above, ideological contestation can be seen in three domains, namely methodology of thought, thought construction, and strategy of struggle.

\section{Thought Methodology}

The fundamental difference between progressive and conservative groups in Muhammadiyah lies in the meaning of tajdid, Muhammadiyah progressive groups interpret purification and dynamism inclusively and contextually. ${ }^{20}$ For them, for purification to remain relevant, it must be synergized and in dialogue with the contemporary social sciences-humanities which continue to develop. ${ }^{21}$ So the ijtihad approach offered includes bayani, burhani, and irfani. ${ }^{22}$ The progressive group also makes use of hermeneutics in the study or development of Islamic thought. Al-Quran which is transcendental-trans-structural and religious historicity cannot be separated as understood by absolutist thinkers,

${ }^{19}$ Haedar Nashir, Understanding Mubammadiyah Ideology (Yogyakarta: Suara Muhammadiya, 2017), p. 30.

${ }^{20}$ Abdul Mu'ti, Deformalization of Islam: Religious Moderation in the Middle of Plurality (Jakarta: Grafindo Khazanah Ilmu, 2004), p. 129

${ }^{21}$ Amin Abdullah, Fresh Ijtibad: Manbaj of Islamic Thought of Mubammadiyah in the Era of Disruption (Yohyakarta: Suara Muhammadiyah, 2019), p. 31.

${ }^{22}$ Azaki Khoirudin and Mu'arif, "Editor's Introduction" in Amin Abdullah, Fresh Ijtihad: Islamic Thought Manhaj Mubammadiyah in the Era of Disruption, p. xix. 
both need dialogical-dialectical-hermeneutical. ${ }^{23}$ Moeslim Abdurrahman underlined the importance of using social hermeneutics and critical social theory. Understanding the Qur'an, apart from knowing the asbabul an-nuzul and the socio-political context when the verse was revealed, the interpreter is required to also understand contemporary social reality. ${ }^{24}$

The breakthroughs of progressive thinkers mentioned above are not without criticism and rejection, as indicated by Syamsul, Hidayat, Yunahar Ilyas, Adian Husaini, and others. ${ }^{25}$ Syamsul Hidayat, said that hermeneutics was born from a Greek, Western, and Christian background which is used to understand the Bible and cannot be used to interpret the Koran. Syamsul argues that hermeneutics is a source of liberalization of the interpretation of the Qur'an which is more dangerous than ta'wil al-ba'id or tafsirul hawa which has implications for the denial and defection of faith, changes in laws (worship, muamalah, and ahwal syahsiyyah). Besides that, Syamsul also assessed that Sufi practices are full of wisdom. ${ }^{26}$

${ }^{23}$ Amin Abdullah, Islamic Studies in Higher Education: an IntegrativeInterconnective Approach, Cet. III (Yogyakarta: Pustaka Pelajar, 2012), p. 207.

${ }^{24}$ Moeslim Abdurrahman, Islam as Social Criticism (Jakarta: Erlangga, 2003), p. 116-123.

${ }^{25}$ Ahmad Nur Fuad, From Reformism to Transformative, p. 170.

${ }^{26}$ Amin Rais, ddk, 1 Century Muhammadiyah: Istiqomah Stops Christianization and Liberalization (Yogyakarta: MTDK-PPM, 2010) .p. 3241. 


\section{Discourse and Thought Construction}

First, religious pluralism. Muhammadiyah progressive figures respond well to the discourse of religious pluralism in contrast to conservative groups who cynically even reject it. For progressive groups, both sociological pluralism in the meaning of humans is indeed created with various backgrounds and theological pluralism which means that many norms are social facts. However, according to Zakiyuddin, conservative groups only accept sociological pluralism. They reject theological pluralism because there is only one norm. ${ }^{27}$ Furthermore, conservatives reject pluralism because they consider that religious pluralism is the same as theosophy which seeks to develop an understanding of the equality of all religions, ignores religious differences, and claims that its teachings are above all religions because it is the essence of all religions. ${ }^{28}$ This is contrary to tauhid because it leads to polytheism. ${ }^{29}$

Second, social justice and gender equality. For Muhammadiyah progressives the scope of the struggle for

27Pradana Boy, Defending Pure Islam, p. 140-142. Zuly Qodir, "Muhammadiyah and Religious Pluralism", in Imron Nasri, ed., Pluralism and Liberalism: the Thought of Muhammadiyah Youths (Yogyakarta: Citra Karsa Mandiri, 2005), p. 88.

${ }^{28}$ Susiyanto and Fathurrahman Kamal, "From Theosophy to Religious Pluralism", in M. Amien Rais M. Syukriyanto AR, et al., 1 Century Mubammadiyah Istiqomah Stress Christianization and Liberalism (Yogyakarta: MTDK-PPM, 2010) h. 144-156.

${ }^{29}$ Adian Husaini, "Introduction" in Budi Handrianto, 50 Indonesian Liberal Muslim Figures Bearers of the Idea of Secularism, Pluralism and Religious Liberalism, Cet. VI (Jakarta: Hujjah Press, 2009), p. xxxi-xxxiv. 
social justice is very broad and crosses boundaries, such as the defense of the weak and oppressed as well as religious minorities, beliefs, and schools that are often cornered. ${ }^{30}$ The latter is not a concern for conservative groups in Muhammadiyah, this is not surprising because it relates to issues of pluralism which conservatives reject. Then in the discourse of gender equality in Muhammadiyah, Siti Ruhaini Dzuhayatin described two periods, namely a period of growth and development. During the growth period or the period of $\mathrm{KH}$ Ahmad Dahlan, the relations between men and women in Muhammadiyah, especially those practiced by KH Dahlan were more of a partnership, namely a senior-junior partnership relationship and under certain conditions accommodating an equal partnership pattern while the development period was until the era contemporary experiences its ups and downs. In the senior-junior partnership pattern, husband and wife are assumed to be comrades in arms who have almost the same role, such as both making a living, making decisions through deliberation, and having the same social activities. However, in the family environment, the husband's position is still dominant, namely as the head of the household, determining family status but in

${ }^{30}$ Ahmad Najib Burhani, "Maintaining Harmony, Maintaining the Integrity of the Nation", Warta Ahmadiyah.Org. 22 November 2017. https://warta-ahmadiyah.org/menjaga-kerukunan-agama-menjagakeutuhan-bangsa-oleh-dr-ahmad-najib-burhani.html (19 October 2020). Ahmad Najib Burhani, Muhammadiyah Progressing: A Shift from Puritanism to Cosmopolitanism (Bandung: Mizan, 2016), p. 109. 
a convergent-accumulative manner. ${ }^{31}$ Dalam konteks kontemporer, kemunduran Muhammadiyah dalam kesetaraan gender terlihat pada Muktamar Muhammadiyah ke-45 di Malang yaitu tidak masuknya perwakilan perempuan dalam struktur pimpinan Muhammadiyah. Selain itu bertentangan juga dengan kenyataan historis aktivisme Muhammadiyah. ${ }^{32}$

\section{Struggle Strategy: Structural and Cultural}

\section{a. Structural}

The joining of the Western-educated generation in the ranks of the Muhammadiyah Central Leadership marked the rise of progressive groups in Muhammadiyah. Figures that can be named, such as Ahmad Syafii Maarif, Moeslim Abdurrahman, Abdul Munir Mulkhan, Amin Abdullah, and Dawam Raharjo. ${ }^{33}$ The Tarjih Council under Amin Abdullah's command gave birth to several very progressive and controversial breakthroughs, such as: establishing the bayani, burhani, and irfani approaches as Muhammadiyah tarjih manhaj, ${ }^{34}$ and the publication of a pro-pluralism book on behalf of the Tarjih Council entitled Thematic Tafsir on Inter-

${ }^{31}$ Siti Ruhaini Dzuhayatin, Muhammadiyah Gender Regime: Contestation of Gender, Identity and Existence (Yogyakarta: Suka Press UIN Sunan Kalijaga Yogyakarta \& Pustaka Pelajar, 2015), p. 161.

${ }^{32}$ Ahmad Najib Burhani, Muhammadiyah Progressing: A Shift from Puritanism to Cosmopolitanism (Bandung: Mizan, 2016), p. 70.

${ }^{33}$ Muhammad Hilali Basya, Muhammadiyah and Salafism in the Transitional Period of Indonesian Democracy: Resistance of Mubammadiyah Scholars to Islamic Revivalism (Yogyakarta: Suara Muhammadiyah, 2020), p. 3.

${ }^{34}$ Ahmad Nur Fuad, From Reformism to Transformative (Malang: Intrans Publishing, 2015), p. 158-162. 
Religious Social Relations. ${ }^{35}$ Conservative groups responded to such progressive actions by boycotting the Thematic Tafsir on Interfaith Social Relations, to heretical and apostate stereotypes from Muhammadiyah and Islam. Also, there was a change back in the nomenclature of MT-PPI to the Tarjih and Tajdid Council, ${ }^{36}$ as well as the electability of Din Syamsuddin at the 45th Muhammadiyah Congress in Malang which was considered the defeat of the progressive-liberal group and the victory of the conservative group. ${ }^{37}$

\section{b. Cultural Path}

1) Establishment of Institutions.

In progressive circles, many cultural institutions collaborate with and receive support from Muhammadiyah elites, among the most prominent such as the Maarif Institute

${ }^{35}$ Center for Cultural Studies and Social Change, Muhammadiyah University of Surakarta, "Profile", PSBPS.Ums.Ac.Id. http://psbps.ums.ac.id/profile/ (30 October 2020). The University of Muhammadiyah Malang, "Center for Islamic Studies and Philosophy", UMM.Ac.Id. http://www.umm.ac.id/id/pages/pusat-studiislamfilsafat.html (30 October 2020. Yayah Khisbiah, "Becoming Muhammadiyah: Positive Social Change in Advancing Islam", Hajriyanto Y. Thohari, eds. , Becoming Mubammadiyah: Autobiography of the Advancing Islamic Movement (Bandung: Mizan, 2016), pp. 264-268.

${ }^{36}$ Ahmad Nur Fuad, From Reformism to Transformative: Muhammadiyah Religious Intellectual Dialectics, p. 172.

${ }^{37}$ The rise of Din Syamsuddin is considered a consequence of puritanism or conservatism that is prevalent in Muhammadiyah and is getting stronger with the inclusion of textualist figures such as Adian Husaini, Syamsul Hidayat, M. Asyorofi after the 45th congress in Malang into the Tabligh Council. Siti Ruhaini Dzuhayatin, Muhammadiyab Gender Regime: Contestation of Gender, Identity, and Existence, p. 246. 
for Culture and Humanity, which was founded by Ahmad Syafii Maarif and assisted by other Muhammadiyah intellectuals, the Young Intellectual Network. Muhammadiyah (JIMM) which was founded by Moeslim Abdurrahman and besides also founded the al-Maun Institute, the Center for the Study of Religion and Civilization founded by Sukidi and Promo U. Thantowi, the Center for Cultural Studies and Social Change (PSBPS) at the Muhammadiyah University of Surakarta, which at the beginning was led by a progressive woman, Yayah Khisbiah. ${ }^{38}$ Later, the Advancing Intellectual Network appeared in half of 2019 which was driven by easy Muhammadiyah figures such as Davil Krisna Alka and Hamzah Fansuri. Unlike the progressive groups, the conservatives themselves do not develop cultural institutions. Although recently there have been several conservative mass organizations that have been initiated by local Muhammadiyah leaders, such as the Anti-Syi'ah National Alliance (ANNAS) and the Hunter of the alienated school of thoughts. . Then in 2017 several Muhammadiyah Karawang Youth activists formed the Al Maidah Command (KOKAM) to participate in the 212 actions. $^{39}$

${ }^{38}$ Muhammad Hilali Basya, Muhammadiyah and Salafism in the Transitional Period of Indonesian Democracy: Resistance of Mubammadiyah Scholars to Islamic Revivalism (Yogyakarta: Suara Muhammadiyah, 2020), p. 85-90.

${ }^{39}$ Tempo, "Action 112, Muhammadiyah Youths Create AlMaidah Guard Command", Tempo. Co.Id, 19 February 2017. https://nasional.tempo.co/read/844768/aksi-112-pemudamuhammadiyah-bikin- commando-kawal-al-maidah $/$ full $\&$ view $=$ ok (30 October 2020). 
2) Dialogue, Seminar, Study, and Publishing

Among progressives, such as the Maarif Institute, there is a School of Thought, which invites various speakers from different backgrounds, from mass organizations, and across faiths. Likewise, JIMM, which annually schedules Tadarus Pemikiran Islam, the participants are the majority of Muhammadiyah young people. To strengthen their thought campaigns, progressive groups actively write both through the Muhammadiyah channel, namely Suara Muhammadiyah, and national media, such as Kompas, Tempo, Media Indonesia, Republika, and others. In 2012 at the University of Muhammadiyah Malang, progressives organized a congress called the International Research Congress on Muhammadiyah. In the congress forum, several auto critics emerged against Muhammadiyah, for example regarding a conservative point of view that continues to be preserved, foreign researchers are no longer interested in researching Muhammadiyah and the unclear membership of Muhammadiyah. As one of the initiators of the congress, Ahmad Najib Burhani said that IRCM was a reflection of the scientific development of young Muhammadiyah intellectuals. $^{40}$

Conservative circles, to stem the thinking of progressives, take it through recitation-recitation, Friday sermons, bulletin. Besides, they are also active in publishing

${ }^{40}$ Ahmad Najib Burhani, Mubammadiyah Progressing: A Shift from Puritanism to Cosmopolitanism (Bandung: Mizan, 2016), p. 75-78. 
Tabligh Magazine and writing books. Several books that specifically respond to the thoughts of Secularism, Pluralism, and Liberalism, namely: Muhammadiyah Thought: Responses to Islamic Liberalization, 1 Century Muhammadiyah Istiqomah Contains Christianization and Liberalization, Mubammadiyah's Interpretation of Da'wah Responses to Cultural Plurality. ${ }^{41}$

\section{3) Cooperate with Other Mass Organizations}

The next strategy is to build relationships with other mass organizations. Muhammadiyah's collaboration with several institutions, such as the Asia Muslim Charity Foundation $(\mathrm{AMCF})^{42}$ is quite helpful for conservative groups. Furqon and Syamsul Hidayat included this pattern of

\footnotetext{
${ }^{41}$ Furqan, The Role of Mubammadiyah in Blocking the Flow of Thinking of Secularism, Pluralism, and Liberalism (Leadership Period 2000-2010, p. 2.

42The collaboration with AMCF which has been going on since 2002 has had a big impact on Muhammadiyah, is the establishment of an Arabic language education institution located within the Muhammadiyah Higher Education (PTM). It was Ma'had Ali Bin Abi Thalib who was first born at the Muhammadiyah University of Yogyakarta, and spread to dozens of other PTMs. Until now, the number of Ma'had managed by Muhammadiyah is $17 \mathrm{Ma}$ 'had. Moqsith Ghazali argues that the various ma'hads do call themselves language education institutions, but the Wahhabi ideology often sneaks in. IslamLib, "Some Reasons Muhamadiyah is Close to Wahabi", Islam-Lib.Com. http://islamlib.com/lembaga/muhammadiyah/b Several-alasanmuhammadiyah-near-dengan-Wahabi/ (31 Oktober 2020). Ahmad Najib Burhani, Muhammadiyah Progressing: Shifting from Puritanism to Cosmopolitanism, p. 186.
} 
cooperation as Muhammadiyah's strategy in stemming secularism, pluralism, and liberalism. ${ }^{43}$

Apart from cooperation with international institutions, Muhammadiyah figures often collaborate with mass organizations which in the Indonesian context are categorized as organizations that promote fundamentalism, radicalism, and Islamism. This phenomenon generally occurs in many regions, for example in cooperation with the Islamic Defenders Front (FPI), the National Anti-Shi'ah Alliance (ANNAS), and Heretical Hunters. ${ }^{44}$

${ }^{43}$ Furqon and Syamsul Hidayat, "The Role of Muhammadiyah in Blocking the Flow of Thinking of Secularism, Pluralism, and Liberalism (Leadership Period 2000-2010)", Tajdida 10, No. 1 (2012): h. 86 - 98. Mas Imam, "Marpuji Ali: Muhammadiyah has cooperated with AMCF for 25 years", Menara-62.Com. 17 December 2017. https://menara62.com/marpuji-ali-muhammadiyah-sudah-25-tahunjalin-kerja-sama-dengan-amcf/ (31 Oktober 2020).

${ }^{44}$ Muhammadiyah, which promotes moderate Islam, is considered incompatible with the methods of the FPI, ANNAS, and Heretical alliances Hunter Army, then again about attitudes towards Ahmadiyah and Shia. At the 47th Muhammadiyah Congress in Makassar in 2015, Muhammadiyah officially produced 13 recommendations, one of which was to create tolerance and harmony between religious communities, to stem takfiri with dialogue, open, intelligent, and enlightening preaching. Indah Wulandari, "Ini 13 Rekomendasi Muktamar Muhammadiyah”, Republika. co.id. 8 Agustus 2015. https://republika.co.id/berita/dunia-islam/islamnusantara/15/08/08/nsr143346-ini-13-rekomendasi-muktamarmuhammadiyah (7 January 2021). 


\section{Conclusion}

Muhammadiyah in religious thought is not singular, but diverse. This is because Muhammadiyah does not have any sect, calls for a return to the Qur'an and Hadith, the Ijtihad and Tajdid movements received different emphases. Among these variants, two of them, such as Progressive and Conservative Islamic thought, are nothing but a historical continuation (continuity and discontinuity) of the early Muhammadiyah apart from being a direct impact of contemporary Islamic thought trends.

First, it is called a historical continuation because the face of Progressive and Conservative Islam in Muhammadiyah is the result of an interpretation of the character of early Muhammadiyah thought with the central figure KH Ahmad Dahlan. The thoughts and movements of $\mathrm{KH}$ Ahmad Dahlan were interpreted differently by later Muhammadiyah generations. Progressive Muslims see $\mathrm{KH}$ Dahlan from the perspective of a rational, inclusive, liberal, thinking and religious model and an ethos of progress. Meanwhile, Conservative Muslims adopted KH Dahlan's mission of purifying Islam. This is the impact of KH Dahlan's thought, which at first glance has a dual character. Second, the construction of Islamic thought in these two variants is intertwined with the situation of contemporary Islamic thought trends and added to the influence of the social, cultural and educational backgrounds in which they live. 
The polarization of the thoughts of the two variants of thought in the Muhammadiyah body is inevitable, both of them contest each other and often negate each other. The ideological contestation takes place in several aspects, such as the methodology of thinking, thought construction, and strategy to market their beliefs.

\section{References}

Abdullah, Amin, (2012). Islamic Studies in Higher Education: an Integrative-Interconnective Approach. Cet. III. Yogyakarta: Student Library.

Abdullah, Amin, (2019). Fresh Ijtihad: Manhaj of Islamic Thought of Mubammadiyah in the Era of Disprruption. Yogyakarta: Muhammadiyah Voice.

Abdurrahman, Moeslim, (2003). Islam as Social Criticism. Jakarta: Erlangga.

Amar, Faodzan, et al, eds, (2012). Reactualization and Contextualization of Islam Advancing in the Middle of Global Civilization. South Jakarta: Al-Wasat Publishing House.

Aminudin, (2019). "Islam Progresif: Telaah Atas Pemikiran Omid Safi”, Farabi Jurnal Pemikiran Konstruktif Bidang Filsafat dan Dakwah, Vo. XVI No. 2.

Boy ZTP, Pradana. Defending Pure Islam. Yogyakarta:

Muhammadiyah Voice, 2016.

Eriyanto, (2006). Discourse Analysis: An Introduction to Media Text Analysis. Cet. V; Yogyakarta: LKIS. 
Fathoni, Farid, (1990). Birth in question: One-fourth of the Mubammadiyah Student Association. Surabaya: Bina Ilmu. Furqan, (2012). "The role of Muhammadiyah in stemming the flow of thoughts on secularism, pluralism, and liberalism (leadership period 2000-2010)". Thesis. Surakarta: Masters in Islamic Thought, Postgraduate Program at the Muhammadiyah University of Surakarta.

Furqon dan Syamsul Hidayat, (2012). "Peran Muhammadiyah Dalam Membendung Arus Pemikiran Sekulerisme, Pluralisme, Dan Liberalisme (Periode Kepemimpinan 2000-2010)", Tajdida X, No. 1.

Hilali Basya, Muhammad, (2020). Muhammadiyah and Salafism in the Transitional Period of Indonesian Democracy: Resistance of Mubammadiyah Scholars to Islamic Revivalism. Yogyakarta: Muhammadiyah Voice.

Masykur Musa, Ali, (2011). Nationalism at the Crossroads: NU's Struggle and Indonesian Nationalism. Jakarta: Erlangga.

Munir Mulkhan, Abdul, (2020). Marhaenis Mubammadiyah. Yogyakarta: Galang Press.

Najib Burhani, Ahmad, (2016). Mubammadiyah Progressed: Shifting from Puritanism to Cosmopolitanism. Bandung: Mizan.

Najib Burhani, Ahmad. Muhammadiyah Java. Cet. II. Yogyakarta: Muhammadiyah Voice, 2016.

Nashir, Haedar, (2017). Understanding the Mubammadiyah Ideology. Yogyakarta: Muhammadiyah Voice. 
Noer, Deliar, (1980). Islamic Modern Movement in Indonesia 19001942. Jakarta: LP3ES.

Nur Fuad, Ahmad, (2015). From Reformism to Transformative. Malang: Intrans Publishing.

Nurhayati, et al, (2018). Muhammadiyah: In the Perspective of History, Organization and Value Systems. Yogyakarta: Trust Media Publishing.

P Guruanto, Hadi. \& Hamdan Juhannis, (2018). Muhammadiyah Pluralists: Relationship between Muslim Puritans, Christians, and Aluk Todolo in Family Education and the Tongkonan Philosophy. Cet. II. Surakarta: Muhammadiyah University Press.

Rais, Amien \& M. Syukriyanto AR, et al., 1 Century Muhammadiyah Istiqomah Stress Christianization and Liberalism. Yogyakarta: MTDK-PPM, 2010.

Shihab, Alwi (2016). Blocking the Flow: The Mubammadiyah Movement's Response to the Penetration of Christian Missions in Indonesia. Yogyakarta: Muhammadiyah Voice. 